\title{
Improvement of Science Learning Outcomes Through the Discovery Learning Model Students of Class V SDN 02 Sarwodadi
}

\author{
Ratih Amelia \\ SD Negeri 02 Sarwodadi \\ ratih.isman@gmail.com
}

\section{Article History}

accepted 01/11/2020

approved 08/11/2020

published 15/11/2020

\begin{abstract}
The purpose of this study is to improve the science learning outcomes competency in analyzing the relationship between ecosystem components with the Discovery Learning model. The subjects in this study were students of class V SDN 02 Sarwodadi, consisting of 14 boys and 6 girls. Classroom Action Research Methods implemented in 3 cycles. The research design starts from the planning stage, action implementation, observation, and reflection. The learning outcomes of students with the application of the Discovery Learning model have increased in each cycle. In cycle I (75\%), cycle II (87.50\%) and cycle III (100\%). Completeness of learning in cycle I (70\%), cycle II (90\% and cycle III (100\%) while the class average in cycle I (76.50), cycle II (83.00), and cycle III $(85,50)$ The conclusion that can be drawn is that learning with the use of the Discovery Learning model can improve science learning outcomes competence in analyzing the relationship between ecosystem components in class V SDN 02 Sarwodadi students.
\end{abstract}

Keywords: Science, Model Discovery Learning, Learning Outcomes

\begin{abstract}
Abstrak
Tujuan penelitian ini yaitu untuk meningkatkan hasil belajar IPA kompetensi menganalisis hubungan antar komponen ekosistem dengan model Discovery Learning. Subyek dalam penelitian ini adalah peserta didik kelas V SDN 02 Sarwodadi, terdiri dari 14 laki-laki dan 6 perempuan. Metode Penelitian Tindakan Kelas dilaksanakan dalam 3 siklus. Desain penelitian mulai dari tahap perencanaan, pelaksanaan tindakan, observasi, dan refleksi. Hasil belajar peserta didik dengan penerapan pembelajaran model Discovery Learning mengalami peningkatan pada setiap siklusnya. Pada siklus I (75\%), siklus II (87,50\%) dan siklus III (100\%). Ketuntasan belajar pada siklus I (70 \%), Siklus II (90\% dan siklus III $(100 \%)$ sedangkan Rata rata kelas pada siklus I $(76,50)$, Siklus II $(83,00)$, dan siklus III $(85,50)$. Kesimpulan yang dapat diambil adalah pembelajaran dengan penggunaan model Discovery Learning dapat meningkatkan hasil belajar IPA kompetensi menganalisis hubungan antar komponen ekosistem pada peserta didik kelas V SDN 02 Sarwodadi.
\end{abstract}

Kata kunci: IPA, Model Discovery Learning, Hasil Belajar

Social, Humanities, and Education Studies (SHEs): Conference Series https://jurnal.uns.ac.id/shes 


\section{PENDAHULUAN}

Pada struktur muatan Kurikulum Tingkat Satuan Pendidikan, Tema Ekosistem termasuk Tema yang ada pada pembelajaran kelas V. Pada kegiatan pembelajaran Tema $\mathrm{V}$ Ekosistem, salah satu kompetensi dasar yang harus dikembangkan adalah menganalis hubungan antar komponen ekosistem dan jaring-jaring makanan di lingkungan sekitar. Tujuan akhir dari pembelajaran ini adalah peserta didik dapat menggolongkan hewan berdasarkan jenis makanannya serta menganalisis daur hidup hewan.

Berdasarkan data pada daftar analisis hasil ulangan kompetensi dasar menganalisis hubungan antar komponen ekosistem dan jaring-jaring makanan di lingkungan sekitar pada peserta didik kelas V SD Negeri 02 Sarwodadi masih tergolong rendah. Terbukti, dari 20 peserta didik kelas $\mathrm{V}$ yang mengikuti ulangan, hanya ada 12 peserta didik atau sebesar 60\% yang tuntas KKM 75. Sisanya, 8 peserta didik atau sebesar $40 \%$ tidak tuntas KKM 75 . Nilai rata-rata kelas baru mencapai 64. Sedangkan, KKM ideal nasional adalah 75 dengan nilai rata-rata kelas minimal 75 dan tingkat ketuntasan minimal sebesar $80 \%$.

Kompetensi dasar menganalisis hubungan antar komponen ekosistem dan jaring-jaring makanan di lingkungan sekitar pada kelas $\mathrm{V}$ semester 1 tergolong materi yang tidak terlalu sulit, namun hasil yang dicapai peserta didik belum sesuai harapan. Ada beberapa masalah yang menyebabkan terjadinya kegagalan dalam pembelajaran menganalisis hubungan antar komponen ekosistem dan jaring-jaring makanan di lingkungan sekitar pada peserta didik kelas V SD Negeri 02 Sarwodadi semester 1 tahun pelajaran 2020/2021, diantaranya (1) pembelajaran masih menggunakan metode konvensional dengan paradigma lama (ceramah), sehingga proses komunikasi dalam pembelajaran berlangsung satu arah saja, (2) pembelajaran masih bersifat transformatif, yaitu memindahkan ilmu dari guru ke peserta didik dengan cara memasukkan ilmu sebanyak-banyaknya, (3) Pembelajaran belum menggunakan model pembelajaran yang dapat mengaktifkan peserta didik, dan (4) pembelajaran belum menggunakan media pembelajaran.

Berdasarkan uraian di atas, maka pembelajaran menganalisis hubungan antar komponen ekosistem dan jaring-jaring makanan di lingkungan sekitar di SD Negeri 02 Sarwodadi harus segera mendapat perhatian yang serius agar dapat mencapai kriteria sesuai yang diharapkan. Mulai dari model pembelajaran yang dipilih oleh guru harus memenuhi kriteria Pembelajaran Aktif Inovatif Kreaktif Efektif dan Menyenangkan (PAIKEM). Salah satunya adalah model Discovery Learning. Dengan menggunakan model Discovery Learning maka pembelajaran akan lebih menarik, bermakna, dan peserta didik memiliki motivasi yang tinggi untuk mengikuti pembelajaran.

Identifikasi masalah dalam penelitian ini adalah : (1) pembelajaran masih menggunakan metode konvensional dengan paradigma lama (ceramah), sehingga proses komunikasi dalam pembelajaran berlangsung satu arah saja., (2) pembelajaran masih bersifat transformatif, yaitu memidahkan ilmu dari guru ke peserta didik dengan cara memasukkan ilmu sebanyak-banyaknya, (3) pembelajaran belum menggunakan model pembelajaran yang dapat mengaktifkan peserta didik, dan (4) pembelajaran belum menggunakan media pembelajaran.

Berdasarkan identifikasi masalah di atas, analisis masalah dalam penelitian ini adalah (1) pembelajaran masih menggunakan metode konvensional dengan paradigma lama (ceramah), sehingga proses komunikasi dalam pembelajaran berlangsung satu arah saja, (2) pembelajaran belum menggunakan model pembelajaran yang dapat mengaktifkan peserta didik.

Bertolak dari latar belakang masalah di atas, rumusan masalah dalam penelitian ini adalah (1) bagaimana proses pembelajaran dengan model Discovery Learning untuk meningkatkan hasil belajar menganalisis hubungan antar komponen 
ekosistem dan jaring-jaring makanan di lingkungan sekitar pada peserta didik kelas $\mathrm{V}$ SD Negeri 02 Sarwodadi semester 1 tahun pelajaran 2020/2021? (2) seberapa besar peningkatan hasil belajar menganalisis hubungan antar komponen ekosistem dan jaring-jaring makanan di lingkungan sekitar setelah dilakukan pembelajaran dengan model Discovery Learning pada peserta didik kelas V SD Negeri 02 Sarwodadi semester 1 tahun pelajaran 2020/2021?

Berkaitan dengan masalah yang telah diuraikan di atas, maka tujuan dilakukannya penelitian ini adalah : (1) Mendiskripsikan kualitas proses pembelajaran dengan menggunakan model Discovery Learning untuk meningkatkan hasil belajar menganalisis hubungan antar komponen ekosistem dan jaring-jaring makanan di lingkungan sekitar pada peserta didik kelas V SD Negeri 02 Sarwodadi semester 1 tahun pelajaran 2020/2021, (2) Mendiskripsikan peningkatan hasil belajar menganalisis hubungan antar komponen ekosistem dan jaring-jaring makanan di lingkungan sekitar setelah dilakukan pembelajaran dengan model Discovery Learning pada peserta didik kelas V SD Negeri 02 Sarwodadi semester 1 tahun pelajaran 2020/2021.

Hasil penelitian ini diharapkan bermanfaat bagi guru dan sekolah, (1) hasil penelitian ini dapat dijadikan acuan dalam memilih model pembelajaran mata pelajaran Ilmu Pengetahuan Alam, khususnya kompetensi dasar menganalisis hubungan antar komponen ekosistem dan jaring-jaring makanan di lingkungan sekitar, dan (2) hasil penelitian ini dapat memberikan kontribusi yang positif bagi sekolah dalam mengembangkan model pembelajaran inovatif.

Pelaksanaan Penelitian ${ }^{\text {METODE }}$ ini merupakan Penelitian Tindakan Kelas (PTK). Subjek dalam penelitian adalah peserta didik kelas V di SDN 02 Sarwodadi. Subjek terdiri dari 20 peserta didik yang terdiri dari 14 laki-laki dan 6 perempuan. Tempat Penelitian ada di SDN 02 Sarwodadi. Penelitian tindakan kelas ini dilakukan pada semester I tahun pelajaran 2020/2021 tepatnya pada bulan Oktober sampai November tahun 2020.

Teknik Pengumpulan data yang digunakan dalam penelitian ini berupa observasi dan tes. Observasi dilaksanakan oleh teman sejawat dengan mengisi lembar observasi untuk mendapatkan data penggunaaan model Discovery Learning pada pembelajaran IPA. Teknik tes untuk mengukur hasil belajar dalam setiap siklusnya.

Instrumen pengumpulan data yang digunakan dalam penelitian ini adalah lembar observasi dan lembar tes evaluasi. Teknik analisis data yang digunakan secara kuantitatif dan kualitatif. Data tentang hasil belajar, yang berupa skor yang diperoleh siswa dari tes evaluasi dianalisis secara kuantitatif dengan menghitung persentase ketuntasan dan nilai rata-rata kelas tiap siklus.Teknik kualitatif untuk menganalisis data hasil observasi penerapan model Discovery Learning dengan menggunakan skala Guttman yaitu dengan menggunakan dua pilihan jawaban ya atau tidak yang disertai deskripsi singkat. Rentang skornya adalah 0 - 1 (0 untuk jawaban tidak, 1 untuk jawaban ya).

\section{HASIL DAN PEMBAHASAN}

Pada bab ini akan dipaparkan hasil-hasil penelitian dan interprestasi terhadap hasil tersebut. Analisis data penelitian dilakukan secara deskriptif kualitatif. Penyajian data hasil penelitian yang akan diuraikan adalah hasil pengamatan terhadap model Discovery Learning yang disajikan guru selama kegiatan pembelajaran berlangsung dan data tes hasil belajar yang diberikan diakhir setiap siklus penelitian.

\section{Pembelajaran IPA}

a. Penggunaan Model Pembelajaran Discovery Learning pada 
Guru memilih penerapan model Discovery Learning pada pembelajaran karena melalui belajar penemuan siswa juga bisa belajar berpikir analisis dan mencoba memecahkan sendiri masalah yang dihadapi. Dari tabel hasil keterlaksanaan model Discovery Learning pada setiap siklusnya, terdapat beberapa kegiatan yang belum dilaksanakan.

Pada siklus pertama, dari 16 aspek kegiatan, terdapat 4 hal yang belum terlaksana. Kegiatan yang belum terlaksana yaitu guru belum membimbing dan mengawasi peserta didik untuk merancang kegiatan penyelidikan, guru belum membimbing peserta didik agar dapat berdiskusi dan membuktikan jawaban permasalahan, guru belum membimbing peserta didik untuk meninjau ulang hasil pengumpulan dan pengolahan data pada buku atau sumber atau literatur lain yang berkaitan dengan materi. Secara persentase, pada siklus I ini tingkat keberhasilan baru di angka 75\%. Pada siklus II, sudah terlaksana 14 aspek kegiatan, pada siklus II ini tingkat keberhasilan model Discovery Learning yang digunakan di angka 87,5\%. Pada siklus III, model Discovery Learning secara lebih maksimal lagi. Berbagai kekurangan yang ada di siklus I dan II diperbaiki, sehingga seluruh aspek yang ada dalam tabel keterlaksanaan dapat terlaksana.

Dengan menampilkan model Discovery Learning, peserta didik terlihat lebih semangat mengikuti pembelajaran untuk mendalami materi yang tersaji. Selain itu, peserta didik lebih fokus memberi perhatian pada materi yang disajikan pada pembelajaran IPA kompetensi dasar menganalisis hubungan antar komponen ekosistem dan jarring-jaring makanan dengan menggunakan media powerpoint, pendidik menampilkan gambar-gambar pendukung materi pembelajaran IPA, yang disertai dengan teks penjelas. Kegiatan ini untuk membantu pendidik dalam memberikan kesamaan terhadap sesuatu yang pada awal pengamatan peserta didik berbeda-beda.

b. Peningkatan Hasil Belajar Peserta didik pada Pembelajaran IPA Kompetensi Dasar Menganalisis Hubungan Antar Komponen Ekosistem dan Jaring-jaring Makanan

Hal kedua yang diamati dalam penelitian ini adalah hasil belajar peserta didik. Hasil evaluasi belajar siswa pada akhir setiap siklusnya dapat diihat dalam Tabel berikut:

Tabel 1 Rentang Nilai Hasil Belajar Peserta didik pada pembelajaran Siklus I, Siklus II, dan siklus III

\begin{tabular}{|c|c|c|c|c|}
\hline No. & Rentang Nilai & $\begin{array}{c}\text { Jumlah } \\
\text { Peserta didik } \\
\text { Siklus I }\end{array}$ & $\begin{array}{c}\text { Jumlah } \\
\text { Peserta didik } \\
\text { Siklus II }\end{array}$ & $\begin{array}{c}\text { Jumlah } \\
\text { Peserta didik } \\
\text { Siklus III }\end{array}$ \\
\hline 1. & $95-100$ & 1 & 2 & 3 \\
\hline 2. & $85-94$ & 2 & 4 & 5 \\
\hline 3. & $75-84$ & 11 & 12 & 12 \\
\hline 4. & $0-74$ & 6 & 2 & - \\
\hline \multicolumn{2}{r}{ Jumlah Nilai } & 1530 & 1660 & 1710 \\
\hline \multicolumn{2}{r}{ Rata-rata Nilai } & 76,50 & 83,00 & 85,5 \\
\hline
\end{tabular}

Nilai rata - rata peserta didik pada siklus I sebesar 76,50, kemudian pada siklus II meningkat menjadi 83,00 dan pada siklus III lebih baik lagi menjadi 85,5. Tingkat ketuntasan belajar peserta didik juga mengalami peningkatan. Pada siklus I terdapat 14 peserta didik yang tuntas $(70 \%)$ dan masih ada 6 peserta didik yang belum Tuntas. Pada siklus II mengalami peningkatan terdapat 18 peserta didik yang tuntas (90\%) dan 
2 peserta didik belum tuntas (10\%) Pada siklus III mengalami peningkatan 20 peserta didik tuntas (100\%). Kenaikan hasil belajar juga dapat dilihat pada grafik batang di bawah ini.

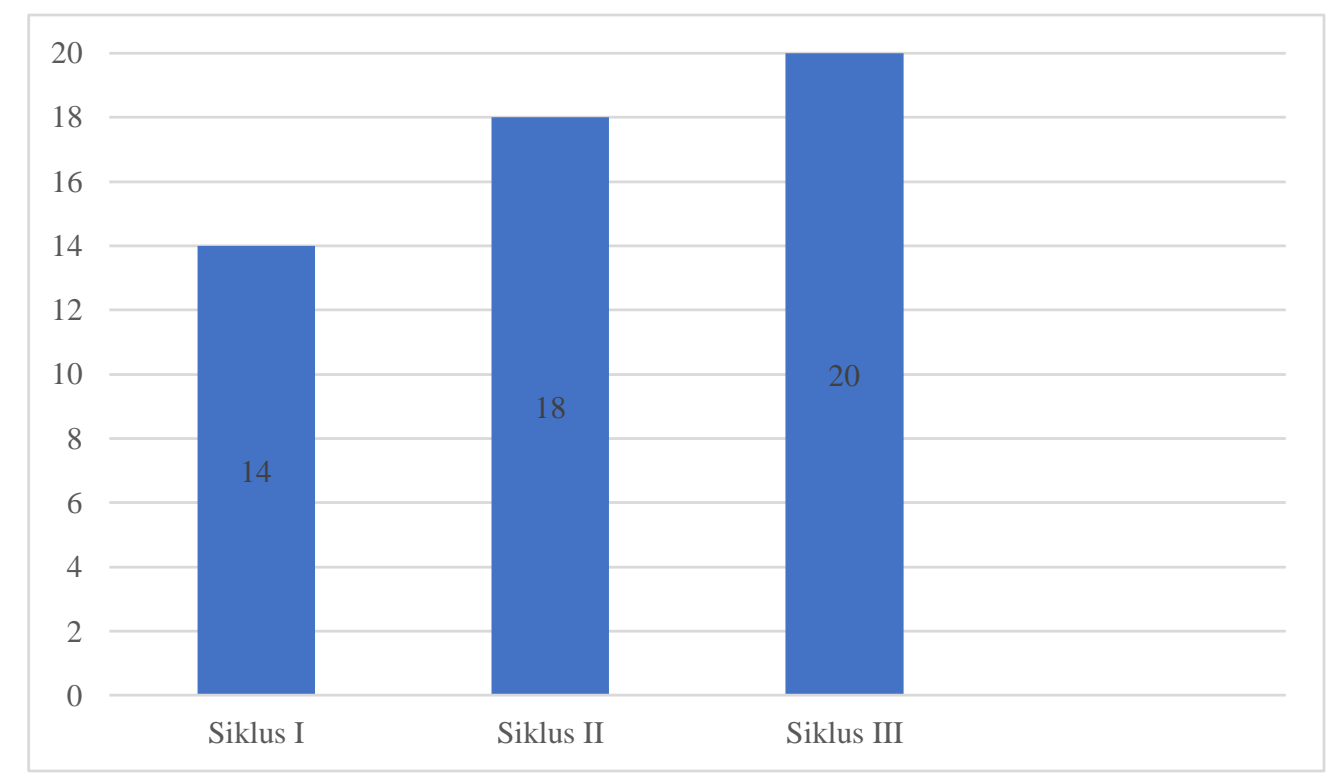

\section{Gambar 1. Diagram Ketuntasan Hasil Belajar tiap siklus}

Berdasarkan grafik di atas, pada siklus I terdapat 14 peserta didik tuntas dengan rincian 1 peserta didik atau sebesar 5\% masuk kategori sangat tinggi, 2 peserta didik atau sebesar $10 \%$ masuk kategori tinggi, 11 peserta didik atau sebesar $55 \%$ masuk kategori sedang, dan 6 peserta didik atau sebesar 30\% masuk kategori rendah, sedangkan pada siklus II mengalami peningkatan yaitu terdapat 18 peserta didik tuntas dengan rincian 2 peserta didik atau sebesar $10 \%$ masuk kategori sangat tinggi, 4 peserta didik atau sebesar $20 \%$ masuk kategori tinggi, 12 peserta didik atau $60 \%$ masuk kategori sedang, dan 2 peserta didik atau sebesar $10 \%$ masuk kategori rendah. Kemudian, pada siklus III mengalami peningkatan 20 peserta didik tuntas dengan rincian 3 peserta didik atau sebesar 15\% masuk kategori sangat tinggi, 5 peserta didik atau sebesar $25 \%$ masuk kategori tinggi, dan 12 peserta didik atau $60 \%$ masuk kategori sedang.

Berdasarkan hasil tersebut menunjukkan bahwa hasil belajar peserta didik meningkat pada setiap siklusnya. Peningkatan hasil belajar peserta didik dapat dilihat dari jumlah peserta didik yang tuntas pada setiap siklusnya. Indikator lain tentunya rata - rata belajar peserta didik yang semakin baik. Hal ini menunjukkan bahwa model Discovery Learning mampu meningkatkan hasil belajar peserta didik.

Peningkatan hasil belajar model pembelajaran Discovery Learning sesuai dengan kajian penelitian yang relevan yang dilakukan oleh Edy Sispariyanto (2019) dalam penelitian yang berjudul "Upaya Meningkatkan Keaktifan dan Hasil Belajar IPA Melalui Model Discovery Learning di Kelas IV SD" dengan hasil keaktifan dan hasil belajar peserta didik meningkat. 


\section{SIMPULAN}

Berdasarkan hasil penelitian pada siswa kelas V SDN 02 Sarwodadi pada pembelajaran IPA kompetensi dasar menganalisis hubungan antar komponen ekositem dan jaring-jaring makanan maka dapat disimpulkan bahwa Penerapan model Discovery Learning dalam pembelajaran IPA mengalami peningkatan. Berdasarkan lembar observasi Pada siklus I mencapai ( $75 \%$ ) dan pada siklus II $(87,5 \%)$ dan pada siklus II meningkat menjadi (100\%). Hasil belajar peserta didik dalam pembelajaran IPA mengalami peningkatkan. Dapat dilihat dari ketuntasan belajar siklus I (70\%). Siklus II $(90 \%)$, dan siklus III $(100 \%)$ dan rata - rata kelas siklus I $(76,50)$, siklus II $(83,00)$, dan Siklus III $(85,5)$.

Setelah melakukan penelitian tindakan kelas dapat disimpulkan bahwa Pembelajaran IPA kompetensi dasar menganalisis hubungan antar komponen ekositem dan jaring-jaring makanan dengan model Discovery Learning dapat meningkatkan hasil belajar peserta didik.

Dari hasil penelitian ini saran yang diberikan semoga dapat berguna untuk kemajuan pengajaran IPA yang diperuntukkan kepada guru dan sekolah. lain yang menggunakan model Discovery Learning, berikut saran yang diberikan: Guru dapat menerapkan media pembelajaran Powerpoint Interaktif pada pembelajaran sebagai salah satu alternatif untuk meningkatkan kualitas pembelajaran dalam meningkatakan hasil belajar peserta didik. Bagi Sekolah, model Discovery Learning dapat diterapkan untuk seluruh mata pelajaran dan dapat dikembangkan dengan media sesuai dengan kebutuhan pembelajaran.

\section{DAFTAR PUSTAKA}

Karitas, Diana Puspita. 2017. Buku Guru Tematik Terpadu Kurikulum 2013 untuk SD/MI Kelas V Tema 5 Ekosistem. Jakarta: Pusat Kurikulum dan Perbukuan, Balitbang, Kemendikbud.

Karitas, Diana Puspita. 2017. Buku Siswa Tematik Terpadu Kurikulum 2013 untuk SD/MI Kelas V Tema 5 Ekosistem. Jakarta: Pusat Kurikulum dan Perbukuan, Balitbang, Kemendikbud.

Wardhani, I G A K., Wihardit, Kuswaya. (2012). Penelitian Tindakan Kelas. Tangerang Selatan : Universitas Terbuka.

Riadi, Muchlisin. (2017). Metode Pembelajaran Penemuan (Discovery Learning). https://www.kajianpustaka.com/2017/09/metode-pembelajaran-penemuandiscovery-learning.html (diakses 13 Oktober 2020, pukul 15.00 WIB)

Siswanti, (2014). Peningkatan Hasil Belajar Meresensi Buku Pengetahuan dengan Metode CIRC. Jurnal Widya Cendekia Dinas Pendidikan Kabupaten Pemalang Volume 1 Edisi 1, halaman 117.

Suyono, Hariyanto. (2016). Belajar dan Pembelajaran. Bandung : PT Remaja Rosdakarya.

Samin, Cah. (2020). Penggolongan Hewan Berdasarkan Jenis Makanannya. https://www.artikelmateri.com/2017/05/penggolongan-hewan-berdasarkanjenis-makanannya-herbivora-karnivora.html (diakses 13 Oktober 2020, pukul 22.21 WIB) 
SHEs: Conference Series 3 (3) (2020) 125-131

Sispariyanto, Edi. Upaya Meningkatkan Keaktifan dan Hasil Belajar IPA Melalui Model

Discovery Learning di Kelas IV https://www.researchgate.net/publication/336276535 UPAYA MENINGKATKA N KEAKTIFAN DAN HASIL BELAJAR IPA MELALUI MODEL DISCOVER Y LEARNING DI KELAS IV SD (diakses 18 Oktober 2020 pukul $14.00 \mathrm{WIB}$ ) 